\title{
Analisis Tingkat Keterampilan Berpikir Kritis Siswa SMA
}

\author{
Endang Susilawati ${ }^{1 *}$, Agustinasari ${ }^{1}$, Achmad Samsudin ${ }^{2}$, Parsaoran Siahaan ${ }^{2}$ \\ ${ }^{1}$ Pendidikan Fisika, STKIP Taman Siswa Bima \\ ${ }^{2}$ Pendidikan Fisika, Universitas Pendidikan Indonesia \\ *Email: endang272012@yahoo.co.id
}

Received: 12 Desember 2019; Accepted: 3 Februari 2020; DOI: http://dx.doi.org/10.29303/jpft.v6i1.1453

Published: 12 Februari 2020

\begin{abstract}
This aim of this research was to analyze students'critical thinking skills. The research was a quantitative descriptive research. The research of critical thinking skills was tested using essay questions. The instrument of critical thinking skills was developed based on Ennis' critical thinking skill indicators, namely: identifying questions, proposing hypotheses, determining an action, considering the use of appropriate procedures, recording observation results, interpreting questions, identifying and dealing with irrelevance, and giving definitions. Based on the research result, $21 \%$ of students had medium critical thinking skills, 64\% of students had low critical thinking skills, and $15 \%$ of students had very low critical thinking skills.
\end{abstract}

Keywords : Critical Thinking Skills; Students

\section{PENDAHULUAN}

Salah satu tujuan pendidikan Abad 21 yaitu mengembangkan keterampilan berpikir peserta didik, salah satunya keterampilan berpikir kritis. Menurut Ennis (2011), berpikir kritis adalah kemampuan berpikir reflektif yang berfokus pada pola pengambilan keputusan tentang apa yang harus diyakini, harus dilakukan dan dapat dipertanggung jawabkan. Keterampilan berpikir kritis sangat diperlukan karena seseorang yang berpikir kritis akan mampu berpikir logis, menjawab permasalahanpermasalahan dengan baik dan dapat mengambil keputusan rasional tentang apa yang harus dilakukan atau apa yang diyakini. Berpikir kritis adalah keterampilan berpikir tingkat tinggi yang berpotensi meningkatkan daya analitis kritis peserta didik. Oleh karena itu, mengembangkan keterampilan berpikir kritis peserta didik dalam pembelajaran menjadi upaya untuk meningkatkan hasil belajar peserta didik.

Penerapan Kurikulum 2013 merupakan upaya untuk meningkatkan keterampilan berpikir kritis peserta didik karena Standar Kompetensi Lulusan (SKL) Kurikulum 2013 yaitu peserta didik dituntut memiliki keterampilan berpikir dan bertindak yang efektif dan kreatif dalam ranah abstrak dan konkret sebagai pengembangan dari melalui kegiatan mengamati, menanya, mencoba, mengolah, menyaji, menalar, dan mencipta secara mandiri sesuai dengan bakat dan minatnya (Kemdikbud, 2013). Keterampilan berpikir kritis merupakan potensi yang dimiliki oleh setiap orang, dapat diukur, dilatih, dan dikembangkan (Lambertus, 2009). Upaya pengembangan keterampilan berpikir kritis yang paling baik yang dapat dilakukan yaitu dengan mengaitkan materi pembelajaran dengan pengalaman nyata peserta didik di lingkungan sehari-hari. Sehingga dalam pembelajaran Kurikulum 2013 perlu dirancang strategi pembelajaran yang memungkinkan pengembangan keterampilan berpikir kritits peserta didik. Strategi memiliki dampak pada daya tangkap peserta didik terhadap hal yang dipelajari (Wingert et al. 2011).

Beberapa penelitian yang dilakukan sebelumnya menyatakan bahwa, keterampilan berpikir kritis peserta didik di wilayah NTB umumnya dapat dilatih dan meningkat dengan menerapkan model- 
model pembelajaran kooperatif, diantaranya seperti penelitian yang dilakukan oleh Nurmayani et al. (2018) di SMA Negeri 6 Mataram bahwa keterampilan berpikir kritis peserta didik pada kelas yang diterapkan model Inkuiri pada aspek keterampilan berpikir kritis seperti klarifikasi dasar, inferensi, penjelasan lebih lanjut, menalar dan pengintegrasian berada pada kategori kritis, sedangkan pada kelas yang tidak diterapkan model pembelajaran kooperatif berada pada kategori kurang kritis. Penelitian yang dilakukan oleh Lestari et al. (2018) menyimpulkan bahwa penggunaan STEM pada kegiatan pembelajaran yang diterapkan dalam bentuk model, bahan ajar maupun lembar kegiatan peserta didik (LKPD) dapat memberikan dampak yang baik, mendukung peningkatan kemampuan berpikir kritis pada aspek inferensi, aspek asumsi, aspek interpretasi, aspek deduksi, aspek evaluasi. Sejalan dengan penelitian yang dilakukan oleh Agustinasari dan Endang Susilawati (2018), pemanfaatan potensi lokal yang diintegrasikan dalam pembelajaran fisika menjadikan pembelajaran lebih kontekstual dan bermakna serta dapat mengasah keterampilan berpikir kritis peserta didik.

$$
\text { Selain itu pegembangan }
$$

keterampilan berpikir kritis tidak hanya dilakukan dalam pembelajaran saja, tetapi juga harus didukung dengan instrumen penilaian yang mencerminkan keterampilan berpikir kritis. Sejalan dengan pendapat Kartimi \& Liliasari (2012) bahwa berpikir kritis memerlukan latihan yang salah satu caranya dengan kebiasaan mengerjakan soal-soal yang mengembangkan berpikir kritis. Maka dalam penelitian ini akan dibahas tentang tingkat keterampilan berpikir peserta didik yang diukur dengan bentuk soal esai yang berbasis keterampilan berpikir kritis. Oleh karena itu, tujuan penelitian ini adalah menganalisis tingkat keterampilan berpikir kritis siswa SMA.

\section{METODE PENELITIAN}

Penelitian ini menggunakan jenis metode deskriptif kuantitatif. Penelitian ini mendeksiprisikan kegiatan keterampilan berpikir kritis siswa.

Subjek penelitian ini adalah siswa SMAN 1 Woha yag pernah mendapatkan materi usaha dan energi. Sampel dalam penelitian ini dipilih secara acak.

Keterampilan berpikir kritis siswa diukur dengan menggunakan soal esai. Soal dikembangkan berdasarkan indikator keterampilan berpikir kritis yang dikembangkan oleh Ennis (2013). Adapun indikator yang diukur adalah: mengidentifikasi pertanyaan, mengemukakan hipotesis, menentukan suatu tindakan, mempertimbangkan penggunaan prosedur yang tepat, merekam hasil observasi, menginterpretasikan pertanyaan, mengidentifikasi dan menangani ketidak relevanan, dan memberi definisi.

Setelah memperoleh hasil penelitian, skor siswa dikonversi menjadi kriteria pada Tabel 1.

Tabel 1. Konversi Skor

\begin{tabular}{ll}
\hline Rentang Skor & Kategori \\
\hline$X>M+1,50 s$ & Sangat Tinggi \\
$M+0,50 s<X \leq M+1,50 s$ & Tinggi \\
$M-0,50 s<X \leq M+0,50 s$ & Sedang \\
$M-1,50 s<X \leq M-0,50 s$ & Rendah \\
$X \leq M-1,50 s$ & Sangat Rendah \\
\hline & Sumber: (Azwar, 2010)
\end{tabular}

Keterangan:

$M=$ Rata-rata skor ideal

$s=$ Standar deviasi

$X=$ Jumlah skor yang diperoleh siswa

Untuk memperoleh nilai siswa, diperoleh menggunaan analisis berikut: 


$$
\text { Nilai }=\frac{\text { skoryangdiperoleh }}{\text { skormasimal }} \times 100
$$

\section{HASIL DAN PEMBAHASAN}

Penelitian ini bertujuan untuk menganalisis tingkat keterampilan berpikir kritis siswa SMAN 1 Woha pada materi usaha dan energi. Data penelitian diperoleh dari hasil tes keterampilan berpikir kritis menggunakan soal uraian. Setelah memperoleh hasil tes, data kemudian dianalisis dan dikategorikan pada tingkat keterampilan berpikir kritis. Perolehan data keterampilan berpikir kritis siswa dapat dilihat pada Tabel 2.

Tabel 2. Deskripsi Keterampilan Berpikir Kritis Siswa

\begin{tabular}{ll}
\hline $\begin{array}{c}\text { Tingkat } \\
\text { Keterampilan } \\
\text { Berpikir Kritis } \\
\text { Siswa }\end{array}$ & Persentase \\
\hline Sangat Tinggi & $0 \%$ \\
Tinggi & $0 \%$ \\
Sedang & $21 \%$ \\
Rendah & $64 \%$ \\
Sangat Rendah & $15 \%$ \\
\hline
\end{tabular}

Hasil penelitian menunjukkan bahwa $21 \%$ siswa memiliki keterampilan berpikir kritis dalam kategori sedang, 64\% siswa dalam kategori rendah, dan $15 \%$ siswa dalam kategori sangat rendah. Tidak ada siswa yang memiliki keterampilan berpikir kritis pada tingkatan tinggi dan dangat tinggi. Hal ini dimungkinkan terjadi karena pembelajaran fisika yang sering dijumpai di sekolah ialah pembelajaran fisika menggunakan pembelajaran langsung dan model ceramah (Ibrahim et al. 2017). Pendapat yang sama juga diungkapkan oleh Maryati et al. (2019) menunjukkan bahwa calon guru masih perlu meningkatkan dimensi pengetahuan tentang strategi dan penyajian pengajaran sains.
Selain menganalisis berdasarkan kemampuan tiap siswa, data juga dianalisis berdasarkan tiap indikator keterampilan berpikir kritis. Pada penelitian ini indikator keterampilan berpikir kritis yang diukur meliputi 8 indikator, yaitu mengidentifikasi pertanyaan, mengemukakan hipotesis, menentukan suatu tindakan, mempertimbangkan penggunaan prosedur yang tepat, merekam hasil observasi, menginterpretasikan pertanyaan, mengidentifikasi dan menangani ketidak relevanan, dan memberi definisi. Berikut merupakan deskripsi keterampilan berpikir kritis siswa tiap indikator.

Tabel 3. Deskripsi Keterampilan Berpikir Kritis Siswa tiap Indikator

\begin{tabular}{ll}
\multicolumn{1}{c}{$\begin{array}{c}\text { Indikator Ketermapilan } \\
\text { Berpikir Kritis }\end{array}$} & Kategori \\
\hline Mengidentifikasi Pertanyaan & Rendah \\
Mengemukakan Hipotesis & Rendah \\
Menentukan suatu tindakan & Rendah \\
$\begin{array}{l}\text { Mempertimbangkan Penggunaan } \\
\text { Prosedur yang Tepat }\end{array}$ & Sedang \\
$\begin{array}{l}\text { Merekam hasil observasi } \\
\text { Menginterpretasikan pertanyaan }\end{array}$ & Sedang \\
$\begin{array}{l}\text { Mengidentidikasi dan } \\
\text { menangani ketidakrelevanan }\end{array}$ & Rendah \\
Memberi definisi & Sedang \\
\hline
\end{tabular}

Berdasarkan hasil analisis tiap indikator keterampilan berpikir kritis, diperoleh bahwa tingkat keterampilan berpikir kritis siswa pada tiap indikator, tergolong pada dua kategori yaitu rendah dan sedang. Dari 8 indikator yang dianalisis, 5 indikator tergolong rendah, dan 3 indikator tergolong sedang.

Pada indikator merumuskan masalah, siswa disajikan satu keadaan kemudian diminta menuliskan dua rumusan masalah dari keadaan tersebut. Beraneka jawaban siswa muncul, ada yang benar dan ada juga yang belum tepat. Ragam jawaban siswa yang belum sesuai dengan rubrik 
diantaranya: 1) Belum paham cara membuat rumusan masalah. Kalimat rumusan masalah ditulis dalam bentuk kalimat pernyataan bukan pertanyaan. 2) Menuliskan rumusan masalah dalam bentuk rumus matematika. Penyebab hal ini terjadi dimungkinkan karena siswa mengartikan secara harfiah arti kata rumusan dalam rumusan masalah. Siswa memaknai rumusan masalah menjadi sebuah masalah yang harus dirumuskan dalam bentuk matematis. 3) Tidak sesuai dengan jumlah rumusan masalah yang diminta. Pada soal ini, jumlah rumusan masalah yang diminta sebanyak dua. Namun, beberapa menulis rumusan masalah satu. 4)Rumusan masalah yang ditulis tidak sesuai dengan konteks materi yang diminta. Hal ni dimungkinkan terjadi karena fisika lebih dikenal sebagai mata pelajaran yang dipenuhi rumus-rumus. Pernyataan ini sejalan dengan yang diungkapkan oleh Rokhmat (2015) bahwa guru fisika memiliki kecenderungan untuk memperkenalkan sejumlah persamaan atau rumus pada fenomena-fenomena terkait.

Pada indikator mengemukakan hipotesis, siswa diminta menuliskan hipotesis dari rumusan masalah yang telah ditulis pada soal pertama. Beberapa hal yang menjadikan jawaban siswa tidak memperoleh nilai maksimal diantaranya: 1 ). Hipotesis yang ditulis tidak sesuai dengan rumusan masalah yang diajukan. Hal ini dimungkinkan terjadi karena siswa belum sepenuhnya paham bahwa hipotesis adalah jawaban sementara dari rumusan masalah. Selain itu, hipotesis yang diuraikan tidak sesuai dengan konteks materi yang diminta. 2) Hipotesis yang diajukan tidak menjawab semua rumusan masalah yang diminta. Pada rumusan masalah ditulis dua rumusan masalah, namun di hipotesis ditulis satu. Hal ini terjadi karena siswa belum memahami bahwa hipotesis adalah jawaban sementara dari rumusan masalah yang ditulis. Hal ini sesuai dengan pendapat Gunawan et al. (2019) bahwa kemampuan siswa dalam menuliskan hipotesis didukung oleh kemampuan siswa dalam merumuskan masalah.

Setelah siswa diminta menuliskan rumusan masalah dan hipotesis, siswa diminta untuk menentukan suatu tindakan berdasarkan masalah yang telah dipaparkan. Pada soal ini, siswa diminta merancang perobaan untuk menjawab rumusan masalah yang telah disusun sesuai dengan deskripsi soal. Beberapa temuan cara siswa menjawab indikator ini adalah: 1) rancangan percobaan yang disusun belum bersifat spesifik memaparkan langkah-langkah percobaan. 2) Rancangan percobaan yang dipaparkan masih bersifat umum dan belum mencerminkan langkah-langkah ilmiah. 3) Langkah kegiatan yang ditulis tidak menjawab rumusan masalah yang disusun.

Pada indikator mempertimbangkan suatu prosedur dengan tepat diperoleh hasil sedang. Pada dasarnya siswa sudah memahami susunan penyelidikan yang diminta berdasarkan masalah yang diberikan. Dari hasil analisis jawaban siswa ditemukan bahwa siswa belum menuliskan langkah percobaan secara sistematis. Sebagian besar langkah-langkah yang ditulis benar, namun urutan kegiatan belum runtun. Di beberapa siswa masih belum memahami langkah-langkah apa yang akan dilakukan.

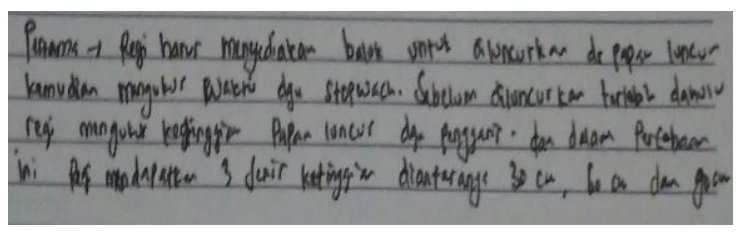

Gambar 1. Contoh jawaban siswa yang belum runtut dalam menjelaskan prosedur.

Indikator selanjutnya yang diukur adalah merekam hasil observasi. Pada indikator ini dipaparkan data percobaan berupa ketinggian dan waktu tempuh. Siswa 
diminta menuliskan data yang dideskripsikan tersebut dalam bentuk tabel. Pada indikator ini, sebagian besar siswa menjawab dengan benar dan skor maskimal Namun, secara keseluruhan total nilai siswa pada indikator tersebut tergolong pada kategori sedang karena selain siswa-siswa yang menjawab benar, banyak juga siswa yang tidak menjawab soal tersebut. Artinya soal ini dilewati sehingga tidak terisi.

Indikator mengeinterpretasikan pertanyaan diukur dengan menampilkan dua keadaan, lalu siswa diminta menginterpretasikan keadaan tersebut. Data menunjukkan bahwa: 1) siswa memberi jawaban yang benar namun alasan yang dipaparkan tidak tepat. Siswa belum tepat dalam menginterpretasikan keadaan yang dipaparkan dengan konsep fisika yang benar. 2) Interpretasi jawaban kurang tepat dan alasan yang dipaparkan kurang relevan.

Selanjutnya, indikator mengidentifikasi dan menangani ketidak relevanan diukur dengan mendeskripsikan keadaan kemudian siswa diminta untuk mengidentifikasi, apakah pernyataan tersebut benar atau tidak. Banyak siswa yang menjawab kurang tepat karena siswa terkecoh dengan asumsi awal di kehidupan sehari-hari. Hal ini juga sejalan dengan penelitian Tamami et al. (2017), bahwa sebagian besar siswa masih menggunakan nalar dalam menjawab suatu permasalahan tanpa didasari konsep yang benar. Selainitu, sebagian siswa menjawab benar namun penjelasan yang dipaparkan kurang lengkap. Selain itu, siswa menjawab dengan jawaban benar namun tidak meberikan alasan. Hal ini dimungkinkan karena siswa baru memahami rumus fisika sebagai persamaan matematis dan belum memahami implementasi dalam kehidupan sehari-hari.

Indikator terakhir yang diukur adalah memberi definisi. Pada indikator ini, ditampilkan gambar dan deskripsi gambar.
Siswa diminta menjelaskan kondisi tersebut berdasarkan definisi fisika. Sebagian besar siswa menjawab salah karena siswa belum memahami kaitan antara deskripsi gambar dengan konsep fisika. Hanya sebagian kecil siswa yang mampu menjelaskan keadaan tersebut dengan konsep fisika yang benar. Sebagian besar siswa menjawab dengan jawaban yang salah dan penjelasan yang tidak relevan.

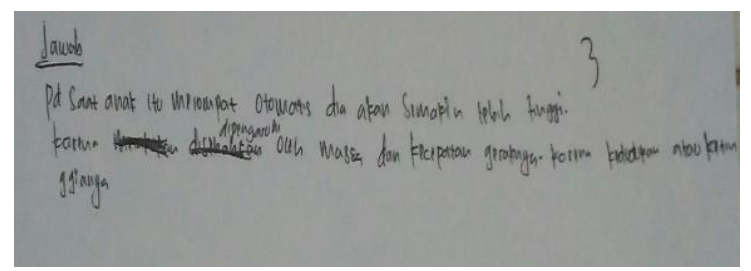

Gambar 2. Contoh jawaban siswa yang belum utuh menjelaskan sesuai konsep fisika.

\section{PENUTUP}

Berdasarkan data hasil penelitian, diperoleh $21 \%$ siswa memiliki keterampilan berpikir kritis sedang, 64\% siswa memiliki keterampilan berpikir kritis rendah, dan $15 \%$ siswa memiliki keterampilan berpikir kritis sangat rendah. Sedangkan hasil analisis tiap inidikator keterampilan berpikir kritis diperoleh bahwa 2 indikator keterampilan berpikir kritis pada kategori sedang dan 6 indikator berada pada kategori rendah.

\section{UCAPAN TERIMAKASIH}

Penulis mengucapkan terimakasih pada donatur penelitian yaitu KEMENRISTEK DIKTI yang telah membantu penelitian ini melalui sumber dana Hibah Penelitian Tahun Anggaran 2019. Terimakasih juga kami ucapkan kepada Ketua dan Lembaga STKIP Taman Siswa Bima yang telah membantu pelaksanaan penelitian sehingga berjalan lancar.

\section{REFERENSI}

Agustinasari \& Susilawati, E. (2018). Inkuiri Berbasis Potensi Lokal dalam Pembelajaran Fisika untuk 
Meningkatkan Keterampilan Berpikir Kritis Siswa SMA. Jurnal Kajian Pendidikan Sains (SPEKTRA), 4 (2), $40-46$

Azwar, S. (2013). Tes Prestasi Fungsi Pengembangan dan Pengukuran Prestasi Belajar. Yogyakarta: Pustaka Pelajar

Lestari, D., Astuti, B., \& Darsono, T. (2018). Implementasi LKS Dengan Pendekatan STEM (Science, Technology, Engineering, And Mathematics) Untuk Meningkatkan Kemampuan Berpikir Kritis Siswa. Jurnal Pendidikan Fisika dan Teknologi, 4(2), 202-207.

Ennis, R. H. (2011). The Nature of Critical Thinking: An Outline of Critical Thinking Disposition and Abilities. University of Illinois. on line at http://faculty.education.illinois.edu/rh ennis/documents/thenatureofcritical thinking_51711_000.pdf

Ennis, R.H. (2013). The Nature of Critical Thinking: Outlines of General Critical Thinking Dispositions and Abilities (Online). Diakses dari http://www.criticalthinking.net/longd efinition.html pada 22 Agustus 2018 21.15 Wita

Tamami, F., Rokhmat, J., Gunadi, I, W., . (2017). Pengaruh pendekatan Berpikir Kausalitistik Scaffolding Tipe 2A Modifikasi Berbantuan LKS Terhadap Kemampuan Pemecahan Masalah Optik Geometri dan Kreativitas Siswa Kelas XI SMAN 1 Mataram. Jurnal Pendidikan Fisika dan Teknologi, 3(1), 76-83.

Gunawan, G., Harjono, A., Hermansyah, H., Heryati, L. (2019). Guided Inquiry Model Through virtual Laboratory to Enhance Students' Science Process Skills on Heat Concept. Cakrawala Pendidikan, 38(2), 259-268.

Ibrahim, I., Kosim, K., \& Gunawan, G. (2017). Pengaruh Model Pembelajaran Conceptual Understanding Procedures (CUPs) Berbantuan LKPD Terhadap
Kemampuan Pemecahan Masalah Fisika. Jurnal Pendidikan Fisika dan Teknologi, 3(1), 14-23.

Kartimi \& Liliasari. (2012). Pengembangan Alat Ukur Berpikir Kritis pada Konsep Termokimia untuk Siswa SMA Peringkat Atas dan Menengah. Jurnal Pendidikan IPA Indonesia, 1(2), 2126.

Kemdikbud. (2013). Kurikulum 2013 Sekolah Menengah Atas(SMA)/ Madrasah Aliyah (MA). Jakarta: Kemdikbud.

Lambertus. (2009). Pentingnya Melatih Keterampilan Berpikir Kritisdalampembelajaranmatematika di sd. Artikel Jurnal Forum Kependidikan, 8(2),

Nurmayani, L., Doyan, A., \& Verawati, N, N, S, P., (2018). Pengaruh Model Pembelajaran Inkuiri Terbimbing Terhadap Kemampuan Berpikir Kritis Peserta Didik. Jurnal Pendidikan Fisikadan Teknologi, 4(1), 23-28.

Maryati, M., Prasetyo, Z. K., Wilujeng, I., \& Sumintono, B. (2019). Measuring Teachers' pedagogical Content Knowledge Using Many-Facet Rasch Model. Jurnal Cakrawala Pendidikan, 38(3), 452-464.

Rokhmat, J. (2015). Penerapan Pendekatan Berpikir Kausalistik Ber-scaffolding dalam Meningkatkan Kemampuan Pemecahan Masalaha Hukum Newton Tentang Gerak. Prosiding Seminar Nasional Fisika.

Wingert, J.R., Wasileski, S.A., Peterson, K., Mathews, L. G., Lanou, A.J., \& Clarke, D. (2011). Enhaching Integrative Experinces: Evidence of Student Perceptions of Learning Gains from Cross-Course Interactions. Journal of The Scholarship of Teaching and Learning, 11(3): 34-57. 